\title{
Implementing Aggregate - Cryptographic Encryption Key for Sharing Data in Cloud Environment
}

\author{
Kumaravel. A, Thirunavukkarasu. S, Rama.A.
}

\begin{abstract}
Sharing is the main convenience for an appropriate restriction. In this study, we deal with the most appropriate framework to ask for significant and flexible sharing of information with others in real motivation driving constrainment. We are diagraming fresh open focal cryptosystems that show the size of the figure texts to such a degree that it is sensible to fairly circle the knowledge of the rights of any cipher text structure. Everything respected, the Secret Key Holder can release a valuable size all around the key for an adaptable choice of ciphertext set in scattered cutoff, some other mixed records referenced outside the set remain.
\end{abstract}

Keywords : Watchwords Short Text Classification, Content-based division, Personal-based structure.

\section{INTRODUCTION}

Disseminated figuring has been seen as a front-line enhancement of IT experience, given its once-over-perplexing, non-essential nature of blowing circumstances in IT history. Power blackouts and security control blackouts of important cloud affiliations are going on angrily. All around, paying little attention to how the redistribution of information to the cloud is monotonous and overhead.[1-10]

\section{A. System Description}

Proposed System Description:In this document, our problem is that "planning a professional open primary encryption conspiracies that underpin adaptable appointment as in any subset of the cipher text (produced by the encryption plot) is unfavorable by a steady-scale unraveling key (produced by the proprietor of the ace mystery key)." In KAC, clients operate the sign under an open key, yet further under an identi. In addition, that discharges that the considered works are kept extremely close to the unmistakable classes. The main proprietor keeps up a star trance called the Ace Stunning Key, which can be used to clear the keys for express courses.[11-15]

B. Systems Architecture:
Revised Manuscript Received on August 22, 2019

Kumaravel.A Assistant Professor, Department of Information and Technology, Bharath Institute of Higher Education and Research, Chennai, India.drkumaravel@gmail.com.

Thirunavukkarasu.S, Assistant Professor, Department of Information and Technology, Bharath Institute of Higher Education and Research, Chennai, India.

Rama.A., Assistant Professor, Department of Information and Technology, Bharath Institute of Higher Education and Research, Chennai, India.

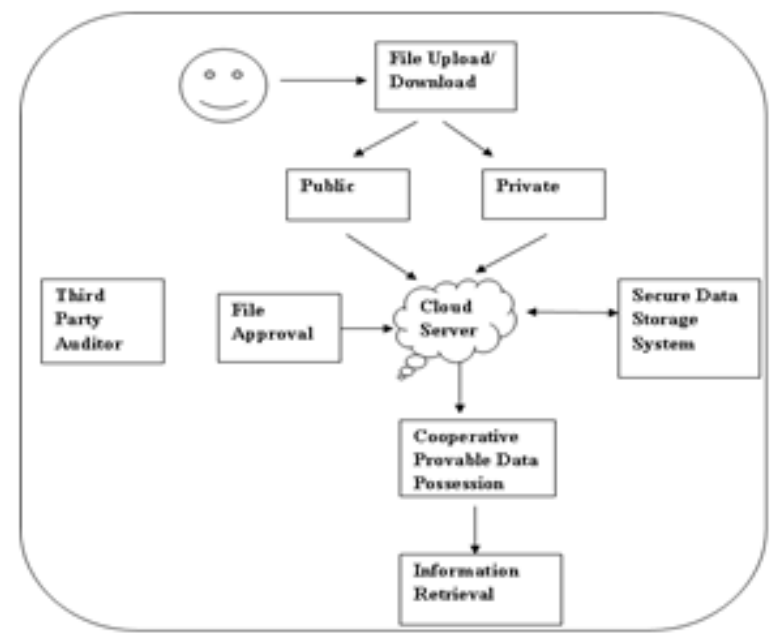

\section{Architecture:}

\section{C.System Analysis}

Scope:This report is a remarkable illustration of the structure's pre-conditions. It is proposed for use by the authorities and will, in the same way, be based on the rationale behind the ongoing application of the framework. Any improvements made to the necessities later on should experience the referenced multi-faceted nature of the support framework..[15-20]

\section{D.User Characteristics:-}

- The client of the structure will be the room chosen by the boss.

- 4. Modules:

- Access Control

- Multi-Encryption Process

- Integrity Control

- Forwarding of data

\section{E. Module Description:}

Access Control: The process of client registration is carried out by the executive in this module. In the event that any customer needs to modify his or her information, he or she shall submit if any client needs to change their data, the individual being fathomed will exhibit the subtleties to the Chairman after the data structure has been restored by the Head.[21-25]

Multi-Encryption Process:. Both exercises have the chance to monitor and control the approval method. In the event that any customer needs to modify his or her information,

he or she shall submit if any client needs to change their data,

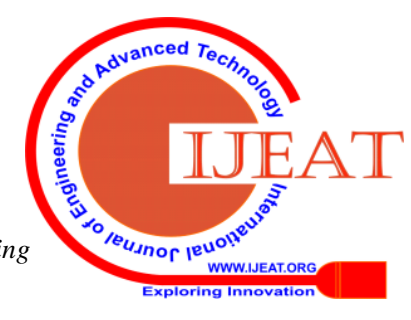


the individual will demonstrate the subtleties to the Chairman after the data structure has been restored by the Head.[26-30] F.Integrity Checking:

Checking uprightness is a way to contrast the scrambled information and the altered content of the figure. In the event of any identification adjustment, the consumer will be informed that the encryption procedure is not legitimately carried out. In the case that there is no recognition adjustment, it will allow the following procedure to be carried out at that stage.

\section{G.Data Forwarding:}

Data forwarding: if paying little regard to anything that any client wants to send their information to their sidekicks or someone they can actually send the encoded data to them. Without downloading a file

\section{OUTPUT SNAPSHOTS:}

Fig.1 File downloaded :

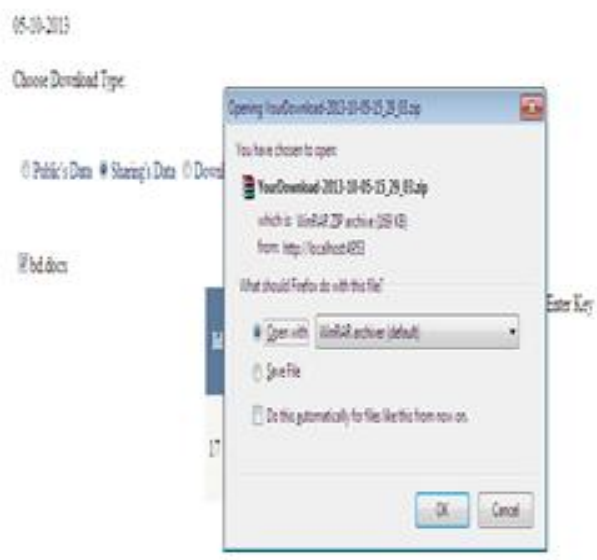

Fig.2 Key sent to your mail I d:

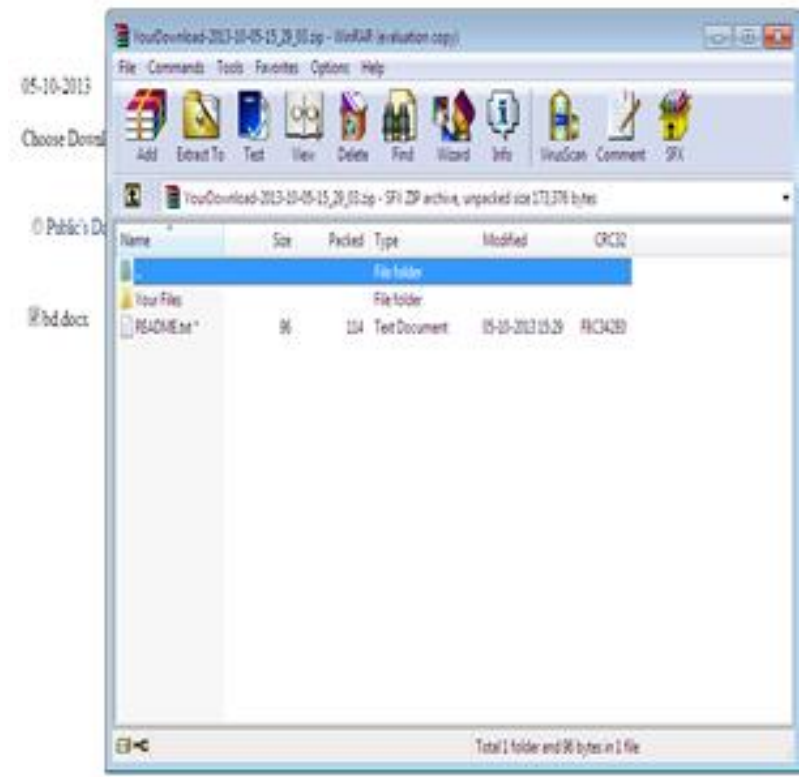

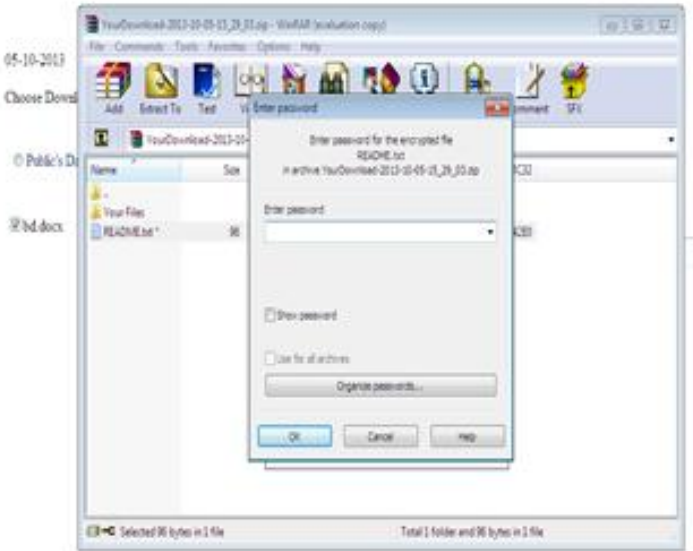

Fig.3Enter the key you have in your mail:

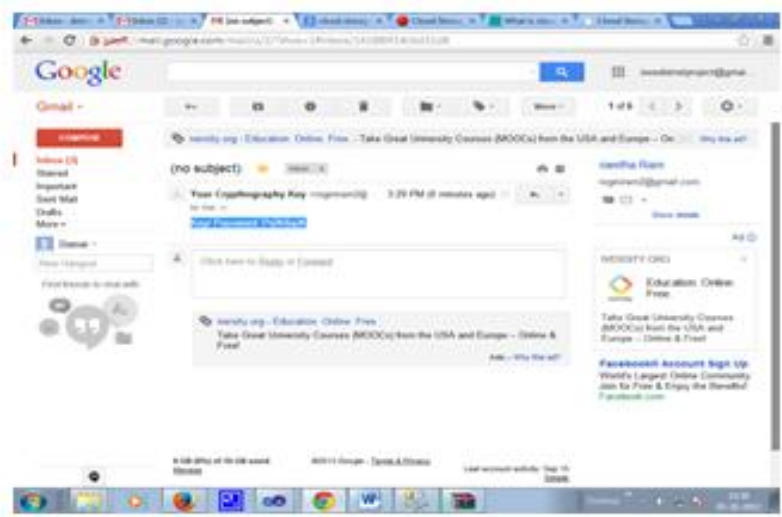

Fig.4The original data is displayed:

1

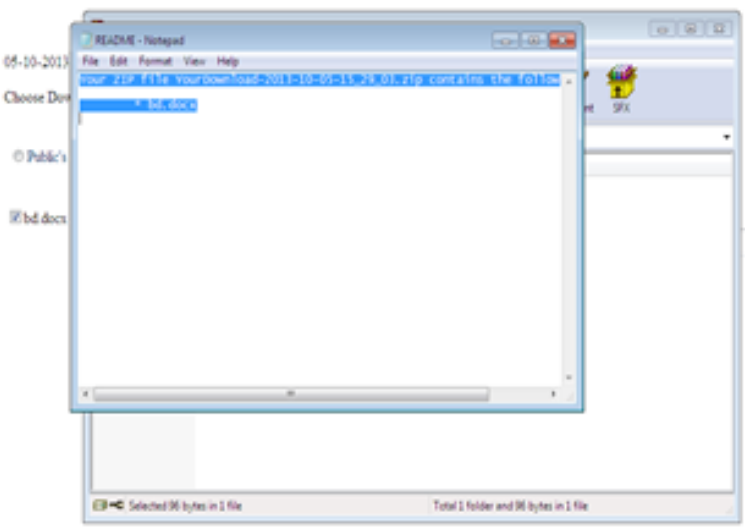

\section{CONCLUSIONS}

We have enhanced the satisfactory implementation of the Key-Outright Cryptosystem (KAC).

In the same manner, we have shown how the KAC focal system can be freed up and joined together to ensure a clear transmission of the key between the different data customers under a powerful data sharing situation. Exposures show that KAC's complete main transmission beats other present secure data structures with respect to execution and versatility.

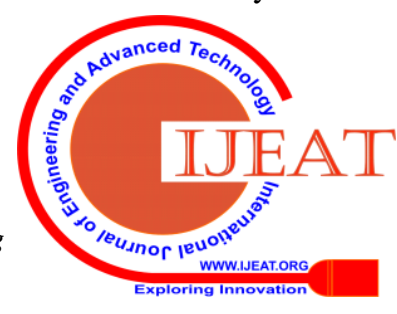




\section{REFERENCES}

1. Gowri Sankaran, B., Karthik, B. \& Vijayaragavan, S.P. 2019, "Weight ward change region plummeting change for square based image huffman coding", International Journal of Innovative Technology and Exploring Engineering, vol. 8, no. 10, pp. 4313-4316.

2. Gowri Sankaran, B., Karthik, B. \& Vijayaragavan, S.P. 2019, "Image compression utilizing wavelet transform", International Journal of Innovative Technology and Exploring Engineering, vol. 8, no. 10, pp. 4305-4308.

3. Kandavel, N. \& Kumaravel, A. 2019, "Offloading computation for efficient energy in mobile cloud computing", International Journal of Innovative Technology and Exploring Engineering, vol. 8, no. 10, pp. 4317-4320.

4. Vinoth, V.V. \& Kanniga, E. 2019, "Reversible data hiding in encrypting images-an system", International Journal of Engineering and Advanced Technology, vol. 8, no. 6, pp. 3051-3053.

5. Selvapriya, B. \& Raghu, B. 2019, "Pseudocoloring of medical images: A research", International Journal of Engineering and Advanced Technology, vol. 8, no. 6, pp. 3712-3716.

6. Senthil Kumar, K. \& Muthukumaravel, A. 2019, "Bi-objective constraint and hybrid optimizer for the test case prioritization", International Journal of Engineering and Advanced Technology, vol. 8 , no. 6, pp. 3436-3448.

7. Kavitha, G., Priya, N., Anuradha, C. \& Pothumani, S. 2019, "Read-write, peer-to-peer algorithms for the location-identity split", International Journal of Innovative Technology and Exploring Engineering, vol. 8, no. 9 Special Issue 3, pp. 445-447.

8. Kaliyamurthie, K.P., Michael, G., Anuratha, C. \& Sundaraj, B. 2019, "Certain improvements in alzheimer disease classification using novel fuzzy c means clustering for image segmentation", Internationa Journal of Innovative Technology and Exploring Engineering, vol. 8, no. 9 Special Issue 3, pp. 599-604.

9. Kaliyamurthie, K.P., Sundarraj, B., Geo, A.V.A. \& Michael, G. 2019, "RIB: Analysis of I/O automata", International Journal of Innovative Technology and Exploring Engineering, vol. 8, no. 9 Special Issue 3, pp. 1019-1022.

10. Velvizhi, R., Rajabhushanam, C. \& Vidhya, S.R.S. 2019, "Opinion mining for travel route recommendation using Social Media Networks (Twitter)", International Journal of Innovative Technology and Exploring Engineering, vol. 8, no. 9 Special Issue 3, pp. 508-512.

11. Kavitha, R., Sangeetha, S. \& Varghese, A.G. 2019, "Human activity patterns in big data for healthcare applications", International Journal of Innovative Technology and Exploring Engineering, vol. 8, no. 9 Special Issue 3, pp. 1101-1103.

12. Pothumani, S., Anandam, A.K., Sharma, N. \& Franklin, S. 2019 , "Extended VEOT framework - Implemented in a smart boutique", International Journal of Innovative Technology and Exploring Engineering, vol. 8, no. 9 Special Issue 3, pp. 762-767.

13. Kaliyamurthie, K.P., Michael, G., Krishnan, R.M.V. \& Sundarraj, B. 2019, "Pseudorandom techniques for the internet", International Journal of Innovative Technology and Exploring Engineering, vol. 8, no. 9 Special Issue 3, pp. 915-918.

14. Aravindasamy, R., Jeffrin Rajan, M., Rama, A. \& Kavitha, P. 2019, "Deep learning provisions in the matlab: Focus on CNN facility", International Journal of Innovative Technology and Exploring Engineering, vol. 8, no. 9 Special Issue 3, pp. 990-994.

15. Theivasigamani, S., Linda, M. \& Amudha, S. 2019, "Object sensing and its identification \& motion sensing", International Journal of Innovative Technology and Exploring Engineering, vol. 8, no. 9 Special Issue 3, pp. 545-549.

16. Mary Linda, I., Vimala, D. \& Shanmuga Priya, K. 2019, "A methodology for the emulation of IPv4", International Journal of Innovative Technology and Exploring Engineering, vol. 8, no. 9 Special Issue 3, pp. 848-852.

17. Velvizhi, R., Priya, D.J., Vimala, D. \& Linda, I.M. 2019, "Increased routing algorithm for mobile adhoc networks", International Journal of Innovative Technology and Exploring Engineering, vol. 8, no. 9 Special Issue 3, pp. 1606-1608.

18. Sangeetha, S., Anuradha, C. \& Priya, N. 2019, "DNS in real world", International Journal of Innovative Technology and Exploring Engineering, vol. 8, no. 9 Special Issue 3, pp. 937-940.

19. Geetha, C., Vimala, D. \& Priya, K.S. 2019, "Constructing multi-processors and spreadsheets with SKIVE", International Journal of Innovative Technology and Exploring Engineering, vol. 8, no. 9 Special Issue 3, pp. 516-519.

20. Yugendhar, K., Sugumar, V. \& Kavitha, P. 2019, "A novel method of univac using fuzzy logic", International Journal of Innovative
Technology and Exploring Engineering, vol. 8, no. 9 Special Issue 3 , pp. 435-437.

21. Kaliyamurthie, K.P., Michael, G., Elankavi, R. \& Jijo, S.A. 2019, "Implementing aggregate-key for sharing data in cloud environment using cryptographic encryption", International Journal of Innovative Technology and Exploring Engineering, vol. 8, no. 9 Special Issue 3, pp. 957-959.

22. Jeffrin Rajan, M., Aravindasamy, R., Kavitha, P. \& Rama, A. 2019, "A novel method of object orientation variation in $\mathrm{C}++$ and java", International Journal of Innovative Technology and Exploring Engineering, vol. 8, no. 9 Special Issue 3, pp. 708-710.

23. Nayak, R., Dinesh, S. \& Thirunavukkarasu, S. 2019, "A novel method improvement of rapid miner for the data mining applications", International Journal of Innovative Technology and Exploring Engineering, vol. 8, no. 9 Special Issue 3, pp. 457-460.

24. Sivaraman, K., Krishnan, R.M.V., Sundarraj, B. \& Sri Gowthem, S. 2019, "Network failure detection and diagnosis by analyzing syslog and SNS data: Applying big data analysis to network operations", International Journal of Innovative Technology and Exploring Engineering, vol. 8, no. 9 Special Issue 3, pp. 883-887.

25. Vimala, D., Linda, I.M. \& Priya, K.S. 2019, "Decoupling online algorithms from erasure coding in DNS", International Journal of Innovative Technology and Exploring Engineering, vol. 8, no. 9 Special Issue 3, pp. 950-953.

26. Rama, A., Kumaravel, A. \& Nalini, C. 2019, "Preprocessing medical images for classification using deep learning techniques", International Journal of Innovative Technology and Exploring Engineering, vol. 8, no. 9 Special Issue 3, pp. 711-716.

27. Sangeetha, S., Srividhya, S.R., Anita Davamani, K. \& Amudha, S. 2019, "A procedure for avoid overrun error in universal synchronous asynchronous receiver transmitter (usart) by utilizing dummy join and interrupt latency method", International Journal of Innovative Technology and Exploring Engineering, vol. 8, no. 9 Special Issue 3 , pp. 657-660

28. Aravindasamy, R., Jeyapriya, D., Sundarajan, B. \& Sangeetha, S. 2019, "Data duplication in cloud for optimal performance and security", International Journal of Innovative Technology and Exploring Engineering, vol. 8, no. 9 Special Issue 3, pp. 1156-1158.

29. Aravindasamy, R., Jeffrin Rajan, M., Sugumar, V. \& Kavitha, P. 2019 "A novel method on developing superblocks and the transistor using apodryal", International Journal of Innovative Technology and Exploring Engineering, vol. 8, no. 9 Special Issue 3, pp. 982-985.

30. Sasikumar, C.S. \& Kumaravel, A. 2019, "E-learning attributes selection through rough set theory and data mining", International Journal of Innovative Technology and Exploring Engineering, vol. 8, no. 10 , pp. $3920-3924$

\section{AUTHORS PROFILE}

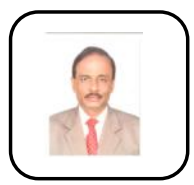

Kumaravel.A Assistant Professor, Department of Information and Technology, Bharath Institute of Higher Education and Research, Chennai, India.

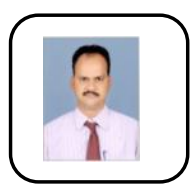

Thirunavukkarasu.S, Assistant Professor, Department of Information and Technology, Bharath Institute of Higher Education and Research, Chennai, India.

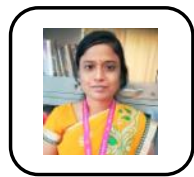

Rama.A., Assistant Professor, Department of Information and Technology, Bharath Institute of Higher Education and Research, Chennai, India. 